\title{
The Evolution of the Roman Calendar
}

\author{
Dwayne Meisner, University of Regina
}

\begin{abstract}
The Roman calendar was first developed as a lunar calendar, so it was difficult for the Romans to reconcile this with the natural solar year. In 45 BC, Julius Caesar reformed the calendar, creating a solar year of 365 days with leap years every four years. This article explains the process by which the Roman calendar evolved and argues that the reason February has 28 days is that Caesar did not want to interfere with religious festivals that occurred in February. Beginning as a lunar calendar, the Romans developed a lunisolar system that tried to reconcile lunar months with the solar year, with the unfortunate result that the calendar was often inaccurate by up to four months. Caesar fixed this by changing the lengths of most months, but made no change to February because of the tradition of intercalation, which the article explains, and because of festivals that were celebrated in February that were connected to the Roman New Year, which had originally been on March 1.
\end{abstract}

\section{Introduction}

The reason why February has 28 days in the modern calendar is that Caesar did not want to interfere with festivals that honored the dead, some of which were 
connected to the position of the Roman New Year. In the earliest calendars of the Roman Republic, the year began on March 1, because the consuls, after whom the year was named, began their years in office on the Ides of March. The calendar of the Republic underwent a series of evolutionary stages before Caesar reformed it in 45 BC. First, it evolved out of a simple lunar system, measuring months by the motions of the moon. Then it developed into a lunisolar calendar, attempting to reconcile Roman months with the actual solar year. By the $1^{\text {st }}$ century BC, it had degenerated as a result of both imprecision and mismanagement until it no longer matched the seasons. When Caesar appointed himself dictator, he felt that there were serious inaccuracies in the Roman calendar and there was need for comprehensive reform. At the very heart of the creation of the pre-Julian calendar was a desire to maintain the correct timing of festivals, so Caesar sought to preserve the mos maiorum or "customs of the ancestors" in his reform. ${ }^{1}$ As a result of this policy, it was essential that February remain its original length, for ritual reasons that will become clear as this article proceeds. To this day, February has 28 days because of Roman festivals that were related to the fact that the original Roman year began on March 1.

The Romans were very practical, and it would have been easy, in one sense, for Caesar to have given February 30 days, by simply reducing July and August, for example, to 30 days; but the Romans were also very religious, and there were religious reasons why February should remain

${ }^{1}$ Macrobius, Saturnalia, trans. Percival Vaughan Davies (New York; London: Columbia University Press, 1969), 1.14.6-10. 
untouched. In order for this to be made clear, we need to have a grasp of the ways in which the Romans measured months and years, and positioned festivals within the year. This article begins with a brief description of the structure of the calendar and its earliest origins as a lunar calendar. In order to correct the discrepancy that inevitably resulted from the calendar's inaccuracies, from time to time an intercalary month was added. After discussing the way this worked, the article looks at how festivals were organized within each month, and how this affected, and was affected by, intercalation. The Terminalia and Regifugium were especially important in their positions relative to the insertion of the intercalary month, and in ways that will become clear as the article proceeds, these festivals were crucial in influencing Caesar's decisions regarding the calendar which, for the most part, we still use today. Therefore, to understand the Roman calendar is to understand the origin of our own calendar.

\section{The Calendar of the Early Republic}

As for the developments of the Roman calendar before the time of Caesar, there are still mysteries and gaps in the evidence, and even in the ancient world, many details were disputed or unknown. There are a number of written sources that enlighten us concerning the Roman calendar, including Ovid's Fasti, Varro's De Lingua Latina, and Macrobius' Saturnalia, but all three authors admitted that they were uncertain about the origin of the names of May and June: did Maius mean maiores ("elders") or the goddess 
Maia, and did Iunius mean iuvenes ("young men") or the goddess Juno? ${ }^{2}$ Beyond such questions, there are problems associated with interpreting each individual author, which are peculiar to that author's intent. Ovid wrote mythological poetry that cannot be considered historical. Varro had etymological theories that modern philologists disregard and Macrobius' support of the traditional view that Romulus and Numa created the first Roman calendars can only be considered legendary. Nevertheless, literary sources provide useful supplements for the actual Roman calendars that have survived.

More than forty inscribed calendars survive, called fasti because of the designation of certain days as fasti and others as nefasti. In order to read a Roman calendar, one must understand the reckoning of nundinae or market days by the letters $\mathrm{A}$ to $\mathrm{H}$, as well as the designation of different kinds of days. These included:

F - fasti: days on which citizens could initiate court cases tried by the praetor urbanus, who spoke the words, do, dico, addico ("I give, I say, I adjudge");

$\mathrm{N}$ - nefasti: days on which the praetor urbanus could not say these words, and public assemblies could not meet;

\footnotetext{
2 Macrobius, Saturnalia, 1.12.16-33; Ovid, Fasti, trans. Sir James George Frazer (London: Heinemann, 1959), 5.1-110, 6.1-100; Varro, De Lingua Latina, trans. Roland G. Kent (London: Heinemann, 1958), 205-207. 
EN - endotercissus: days that were nefasti in the morning when a sacrifice was prepared and in the evening when it was offered, but were fasti in between;

C - comitialis: days on which public assemblies could meet; and

NP - no one is quite sure what this meant, but there have been reasonable guesses (e.g. nefasti publici). ${ }^{3}$

Thus, Roman calendars were called fasti because they were a way of determining which days were fasti and which ones were not. Most surviving fasti date from the early Principate, such as the Fasti Praenestini, the largest Roman calendar to have survived, but only one pre-Julian calendar has been found, the Fasti Antiates Maiores, painted in red and black on plaster between 84 and 46 BC. ${ }^{4}$ Many fasti are in fragments, but by combining them with literary evidence and modern astronomy as I illustrate below, scholars have been able to reconstruct the calendar of the Republic. But what has been achieved is a partial reconstruction because many aspects of the Republican calendar remain uncertain.

In the prehistoric agricultural settlements which later evolved into the city of Rome, there would not have been a need for a very precise calendar because rural farmers needed only to follow the signs of the changing

\footnotetext{
${ }^{3}$ H.H. Scullard, Festivals and Ceremonies of the Roman Republic (London: Thames \& Hudson, 1981), 42-45.

${ }^{4}$ Ibid., 5-8. 
seasons, timing their activities around growing seasons and the phases of the moon. During the course of the Regnal Period (753-510 BC), however, Roman cult began to require a method of organizing annual agricultural festivals. The pontifices created a system of reckoning time according to the phases of the moon, resulting in a lunar calendar. The new moon marked the beginning of the month, the Kalends, which the pontifex maximus announced to the king at the first spotting of the new moon. ${ }^{5}$ The full moon was the Ides, and fell either 13 or 15 days after the Kalends, depending on whether the month was 29 or 31 days long. Nine days before the Ides, either the $5^{\text {th }}$ or the $7^{\text {th }}$ day of the month, was the Nones (nonae = "nine"), which corresponded with the first quarter moon, and on this day the rex sacrorum gathered an assembly of people on the Capitoline to announce the days on which festivals would be held. ${ }^{6}$ In this way, the earliest official Roman system of measuring time was created out of ritual concerns, based in effect on the agricultural cycle and on lunar phases; the Kalends on the new moon, the Nones on the first quarter, and the Ides on the full moon. Festivals were arranged in relation to these days. For example, the Parilia was on April 21 and was expressed as the tenth inclusive day before the Kalends of May (X Kal. Maius). ${ }^{7}$ This system worked

${ }^{5}$ E.J. Bickerman, Chronology of the Ancient World (London: Thames \& Hudson, 1968), 17-18, 44; R.M. Ogilvie, The Romans and their Gods in the Age of Augustus (London: Chatto \& Windus, 1969), 72-73.

${ }^{6}$ Macrobius, Saturnalia 1.15.9-13; Scullard, Festivals and Ceremonies, 42-43.

7 See Appendix A. NB: Whereas we count exclusively, and would say that February 24 occurs five days before March 1, the Romans counted inclusively, which means that they included March 1 in their reckoning; thus, in the Roman mind, what we would call February 24 occurred on the sixth day before the 
reasonably well within the context of a month, but did not address the length of the year. This was where the Romans, along with many other ancient cultures, had centuries of difficulty.

Macrobius credits Romulus with establishing the first Roman calendar, in which the year began in March, an obviously legendary account, but for sake of simplicity I will call this the Romulan calendar. ${ }^{8}$ For a rural agricultural society, it made sense to mark the beginning of the year in what we call March, for it was the beginning of spring, when everything in nature came back to life and the crop cycle began with spring planting. This way of perceiving the year was analogous to the way the earliest Romans perceived the day. Before sundials or water clocks were introduced to Rome, they reckoned the beginning of day as sunrise and the end of the day as sunset. ${ }^{9}$ As the day began with the rising of the sun, and the month began as the new moon began to wax, so the year began with the opening up of spring.

The problem with this system was that by measuring months according to the moon, it did not take long before the calendar no longer matched the seasons, and this was not good for a religious system that was often centered on agricultural festivals. The effect would have been worse in the case of the ten-month year, which

Kalends of March. This article makes clear when a number is reckoned inclusively.

8 Macrobius, Saturnalia 1.12.3.

9 Jérôme Carpocino, Daily Life in Ancient Rome, trans. E.O. Lorimer (London: Penguin Books, 1956), 161-169; Bickerman, Chronology of the Ancient World, 13.

Past Imperfect 
ancient scholars concluded was the case with the Romulan calendar, as shown below: ${ }^{10}$

$\begin{array}{ll}\text { Martius }-31 \text { days } & \text { Quintilis }-31 \text { days } \\ \text { November }-30 \text { days } & \\ \text { Aprilis }-30 \text { days } & \text { Sextilis }-30 \text { days } \\ \text { December }-30 \text { days } & \\ \text { Maius }-31 \text { days } & \text { September }-30 \text { days } \\ \text { Iunius }-30 \text { days } & \text { October }-31 \text { days }\end{array}$

Macrobius, writing in the $4^{\text {th }}$ century AD, argued that this was evident from the fact that Quintilis, Sextilis, September, October, November, and December were all named according to numbers, ${ }^{11}$ but Januaris and Februaris were not. Fowler, writing in the $19^{\text {th }}$ century AD, argued that the reason why January and February were not numbered was not that they were late additions. Rather, it was because of their religious significance that they were not numbered. ${ }^{12}$ This argument is somewhat convincing when one considers the festivals that occurred between January and March, as I do below, but even if Macrobius' account is correct, the year would have lasted 304 days, and it would not have taken long for the Romans to realize that the calendar did not coincide with the seasons. Romulus, as Ovid says, was "better versed in swords than stars," 13 but Macrobius assures us that Numa, the second legendary king of Rome

\footnotetext{
10 Ovid, Fasti 1.27; Macrobius, Saturnalia 1.12.3-4; W. Warde Fowler, The Roman Festivals of thePeriod of the Republic (Piscataway, NJ: Gorgias Press, 2004), 2-3; Michels, The Calendar of the Roman Republic, 122-123.

11 Macrobius, Saturnalia 1.12.5.

12 Fowler, The Roman Festivals, 4-6.

13 Ovid, Fasti 1.30 .
} 
after Romulus, created January and February, and changed the lengths of some of the months. ${ }^{14}$ Thus, we may call the following list the Numan calendar:

$\begin{array}{ll}\text { Martius }-31 \text { days } & \text { Quintilis }-31 \text { days } \\ \text { November }-29 \text { days } & \\ \text { Aprilis }-29 \text { days } & \text { Sextilis }-29 \text { days } \\ \begin{array}{l}\text { December }-29 \text { days } \\ \text { Maius }-31 \text { days }\end{array} & \text { September }-29 \text { days } \\ \text { Januaris }-29 \text { days } & \\ \text { Iunius }-29 \text { days } & \text { October }-31 \text { days } \\ \text { Februaris }-28 \text { days } & \end{array}$

Despite some minor adjustments, the Numan calendar was the basis of the Republican calendar, which was lunisolar, a calendar that attempted to reconcile the measurement of time between the sun and the moon. ${ }^{15}$

The fundamental weakness of this calendar was that it had 355 days, which fell short of the $3651 / 4$ days of the natural solar year. After a few years this would have been noticeable, so throughout the Republic, the pontifices attempted to correct this imbalance through intercalation. The way in which Roman intercalation worked was that every second year, either 22 or 23 days were added to the end of February, which would be cut off on either February 23 or 24 , depending on how many extra days the pontifices thought were needed, and a 27-day intercalary month,

14 Macrobius, Saturnalia 1.13.1-3.

15Marcus Tullius Cicero, De Re Publica, trans. James E.G. Zetzel (Cambridge \& New York: Cambridge University Press, 1999), 1.25. Because of a solar eclipse on June 21, $400 \mathrm{BC}$, which Cicero records as having happened on the Nones of June (June 5), $401 \mathrm{BC}$, it is generally accepted among modern scholars that the Republican calendar was established by the $5^{\text {th }}$ century BC, most likely by the decemviri, who in $450 \mathrm{BC}$ wrote the Twelve Tables. 
named Intercalaris or Mercedonius, was inserted. In a sense, the last five days of February were moved to the end of the intercalary month. February was split after February 23 or 24 , and either 22 or 23 days were put in between. ${ }^{16}$

\section{Intercalation and Annual Festivals}

The relationships between February and the intercalary month are best understood by considering the festivals that occurred at that time of the year. To begin with, the argument that February was the last month of the Roman ritual year can be supported by indications of the ritual meaning of the month itself. February was not rich with joyful celebrations. The name Februaris was based on the word februum, which referred to an object used for purification; februum was the word used for the strips of goatskin that were used in the Lupercalia (February 15) as instruments of purification. ${ }^{17}$ In the Lupercalia, two men called Luperci dressed in goat skins to commemorate the she-wolf who had suckled Romulus and Remus. Running past the crowds, the Luperci struck spectators who eagerly waited to receive ritual purification in this way. ${ }^{18}$ In addition to this dark but popular ritual, the days from February 13 to 21 were dies parentales, a time of honoring the dead, which culminated in the Feralia on February 21. During these days, temples were closed and marriages

\footnotetext{
16 Michels, The Calendar of the Roman Republic, 16; Robert Hannah, Greek and Roman Calendars (London: Duckworth Publishers, 2005), 106-110.

17 Ovid, Fasti 2.3-54; Fowler, The Roman Festivals, 301-302.

${ }^{18}$ Scullard, Festivals and Ceremonies, 77. 
were forbidden, as citizens performed solemn duties to their ancestors. ${ }^{19}$ Death and purification were somber themes that signaled the end of the year and preparation for the beginning of the next one.

The Kalends of the intercalary month occurred on the day after the Terminalia (February 23), and Varro regarded the origin of the festival's name in that it was "set as the last day of the year." 20 In reality, the festival was named after Terminus, the god of boundaries, and the Terminalia re-established annually the legitimacy of rural boundaries, which were marked by stones. Two or more landowners brought garlands and cakes to the boundary stones at the edge of their neighbouring properties, each to his side of the stone. The stone was sprinkled with the blood of a sacrificed lamb or pig, and after the ritual, the neighbours shared in a feast. ${ }^{21}$ It is unclear whether this explicitly means that Terminus also marked the boundary between one year and the next, but the Terminalia continued to mark the day before the intercalary month.

On years in which there was no intercalation, the Terminalia was immediately followed by the Regifugium, which commemorated the flight of the Tarquins from Rome at the beginning of the Republic. ${ }^{22}$ When there was intercalation, the Regifugium was moved to the $23^{\text {rd }}$ day of the intercalary month. More precisely, in either case, the Regifugium occurred on the sixth day before the Kalends of

${ }^{19}$ Fowler, The Roman Festivals, 306-309.

${ }^{20}$ Varro, De Lingua Latina 6.13.

21 Ovid, Fasti 2.639-684; Fowler, The Roman Festivals, 324-325; Scullard, Festivals and Ceremonies, 79-80.

22 Ovid, Fasti 2.685-852; Fowler, The Roman Festivals, 327. 
March (VI Kal. Martius), counting inclusively. ${ }^{23}$ On the third inclusive day before the Kalends of March (either February 27 or Intercalaris 26), the Romans enjoyed horse-races in the celebration of the Equirria, which was sacred to Mars and was celebrated again on March $14 .{ }^{24}$ The Roman method of intercalation was careful, therefore, to ensure that the Terminalia retained its position relative to the Ides of February, and that the Regifugium and Equirria retained their positions relative to the Kalends of March. The reason for this, arguably, was that the Kalends of March was the first day of the ritual year. February was a sullen month, characterized by ritual purification and commemoration of the dead, a closing down of the old in preparation for the new, but when the Romans celebrated the Equirria, the tone of the rituals changed.

The Roman New Year was marked by the Feriae Marti, a festival of Mars, and indeed, the entire month was named after him. In fact, Mensis Martius ("the month of Mars") ${ }^{25}$ was, of all the months in the Roman calendar, the only one unequivocally named after a specific deity. Two rituals, in particular, indicate that the Kalends of March was the beginning of the year: this was the day that the Vestal Virgins renewed the fire in the Temple of Vesta, and it was also the day that fresh laurels were brought to decorate the Regia. ${ }^{26}$ The Equirria, which occurred three inclusive days

\footnotetext{
23 Scullard, Festivals and Ceremonies, 81.

24 Ovid, Fasti 2.856-864; Fowler, The Roman Festivals, 330-331; Scullard, Festivals and Ceremonies, 82.

25 R.M. Ogilvie, The Romans and their Gods in the Age of Augustus (London: Chatto \& Windus, 1969), 78.

26 Ovid, Fasti 3.135-144; Scullard, Festivals and Ceremonies, 85.
} 
before the Kalends of March, was repeated on March 14, ${ }^{27}$ and a feast to Anna Perenna was celebrated on the Ides of March, a joyful, drunken picnic on the banks of the Tiber, in honor of a goddess who personified the year. ${ }^{28}$ March was naturally a month when Romans opened up fresh activity in both agriculture and war, two activities that were closely related to Mars, ${ }^{29}$ and that fit the notion of the beginning of spring as the beginning of the year. The character of Mars can be seen in the dance of the Salii, who on the last day before March put on Bronze Age armour and danced every day until March 19 - the Quinquartus - to purify their weapons, and symbolically, the entire army. ${ }^{30}$

After all of these feriae ("festivals"), those between April and August revolved around agricultural activities: the Vinalia, celebrated on April 23 and August 19, celebrated two different aspects of making wine; ${ }^{31}$ on April 19, the Cerialia involved sacrifices to Ceres asking her for good crops; 32 and on August 21, Consus, the god of the granary, was honored in the Consualia to celebrate the end of harvest. ${ }^{33} \mathrm{By}$ mid-October, the ritual flavour of the calendar shifted toward endings: on the Ides of October, one of the winning horses in a chariot race in the Campus Martius was sacrificed; and on October 19, the arms and weapons of the army were purified in the Armilustrium, a

27 Ovid, Fasti 3.517-522.

28 Ovid, Fasti 3.523-542; Scullard, Festivals and Ceremonies, 90.

${ }^{29}$ Fowler, The Roman Festivals, 64-65.

30 Scullard, Festivals and Ceremonies, 93; Ogilvie, The Romans and their Gods, 79.

31 Varro, De Lingua Latina 6.16, 20; Scullard, Festivals and Ceremonies, 106-108, 177.

32 Varro, De Lingua Latina 6.15; Scullard, Festivals and Ceremonies, 102-103.

33 Varro, De Lingua Latina 6.20; Scullard, Festivals and Ceremonies, 177-178. 
festival of Mars to mark the end of the war season. ${ }^{34}$ Analogous to the period of sunshine between dawn, when the day opened, and dusk, when the day closed, as March and April were a time of opening, so August and October were a time of closing, when the crops and the battles gave way to the nighttime of winter. At the center of this winter was Mentis Januaris, which ancient authors believed (not without uncertainty) was named after Janus, the god of the threshold, who sees time both before and after, looking both forward and backward. 35 Ovid writes of "two-headed Janus," 36 and Varro calls him "the god who is first in order," 37 but both of these authors lived long after January had replaced March as the first month of the year.

No one is certain when the Kalends of January became the first day of the year in the Roman calendar. It may have been early in the Republic, but at the latest, it must have been done by $153 \mathrm{BC}$, when the beginning of the consular year, which had previously been the Kalends or March, was changed to the Kalends of January. The civic year, being eponymous, began on the day the consuls took office, the Kalends of January, but the annual ritual cycle continued as before. This had the practical value of allowing the consuls time to take care of administrative matters before war season began, but more importantly, it brought the calendar more in line with the solar year, by

34 Varro, De Lingua Latina 6.22; Scullard, Festivals and Ceremonies, 193-195.

35 Maurizio Bettini, Anthropology and Roman Culture, trans. John Van Sickle (Baltimore \& London: John Hopkins University Press, 1991), 127-129.

36 Ovid, Fasti 1.63.

37 Varro, De Lingua Latina 6.34

Past Imperfect 15 [2009] | ( ) | ISSN 1711-053X | elSSN 1718-4487 
beginning the new year closer to the winter solstice. ${ }^{38} \mathrm{In}$ principle, this was an improvement, but in practice, the lunisolar year and intercalary month continued to ensure that absolute precision was impossible.

With intercalation, every period of four years had 1,465 days, which still did not correspond to four solar years, having 1,461 days. ${ }^{39}$ Every $1821 / 2$ years, the winter solstice would have fallen in mid-summer, and farmers would have found themselves celebrating harvest festivals during spring planting. Further adjustment was periodically necessary, and this was left in the hands of the pontifices. We have very little evidence concerning the accuracy of their adjustments in the early period, but by 191 BC, the calendar was four months off, perhaps because intercalation had been ignored during the Second Punic War (218-202 BC). Livy records a solar eclipse as having happened on July 11 in 191 BC, but it actually occurred on March 14, an error of 117 days. ${ }^{40}$ Some attempts were made to restore the calendar, and by $168 \mathrm{BC}$ it was somewhat closer to the mark. A lunar eclipse that occurred on June 21 that year was recorded by Livy as having occurred on September 3, an error of 72 days. ${ }^{41}$ From 150 to $70 \mathrm{BC}$, the calendar was roughly in tune with the

\footnotetext{
38 Fowler, The Roman Festivals, 5. If, for a period of time, the civic year and the ritual year began in different months, this should not be difficult to grasp, for our calendar month begins in January, while our school month begins in September.

${ }^{39}$ Samuel, Greek and Roman Chronology, 159; Bickerman, Chronology of the Ancient World, 46.

40 Livy, Ab Urbe Condita, trans. E.T. Sage (London: Heinemann, 1965), 37.4.4.

${ }^{41}$ Livy, Ab Urbe Condita 44.37.8-9; Michels, The Calendar of the Roman Republic, 102; Bickerman, Chronology of the Ancient World, 46.
} 
seasons, but between 66 and 46 BC there grew an error of 90 days. ${ }^{42}$ This may have been simply because the pontifices found the intercalary system confusing, but ancient and modern authors have suggested that they interfered with intercalation for political reasons, such as prolonging magistracies, collecting extra interest for taxcollectors, or delaying legislation. ${ }^{43}$ Whatever the reasons, by the time of Caesar's reform, the Roman calendar was severely flawed.

\section{Caesar's Reforms of the Calendar}

In the years leading up to the Battle of Pharsalus (48 BC) and the self-appointment of Gaius Julius Caesar as dictator, the pontifices had neglected intercalation, some using it as a political weapon, ${ }^{44}$ to the point where, as Suetonius relates, "the harvest festivals did not come in summer nor those of the vintage in the autumn." 45 Caesar resolved to fix this problem. We learn from Plutarch that he consulted with "the best philosophers and mathematicians." 46 Macrobius mentions Marcus Flavius, who assisted him, ${ }^{47}$ and we learn from other sources that

42 Samuel, Greek and Roman Chronology, 162-164; A.W. Lintott, "Nundinae and the Chronology of the Late Roman Republic," The Classical Quarterly, New Ser., Vol. 18, No. 1 (May, 1968), 190-191.

43 Lintott, "Nundinae," 191; Macrobius, Saturnalia 1.14.1.

${ }^{44}$ Zwi Yavetz, Julius Caesar and his Public Image (London: Thames \& Hudson, 1983), 112-113.

45 Suetonius, De Vita Caesarum, trans. J.C. Rolfe (London: Heinemann, 1964), 40.1 .

46 Plutarch, Caesar, trans. Bernadotte Perrin (London: Heinemann, 1967), 59.23.

47 Macrobius, Saturnalia 1.14.2. 
when Caesar was in Egypt with Cleopatra, he consulted with Egyptian and Greek astrologers, including Sosigenes. ${ }^{48}$ Before he could begin the first year of the Julian calendar, he needed to extend $46 \mathrm{BC}$ to bring it in line with the solar year. The solution he found was to make $46 \mathrm{BC}$ an intercalary year, and to add 67 extra days (three intercalary months) between November and December, ${ }^{49}$ and as a result, $46 \mathrm{BC}$ was 445 days long. January 1, $45 \mathrm{BC}$ was the first day of the first year to be measured by the Julian calendar. 50

As noted before, the lunar year is 355 days long, which makes it $10 \frac{1}{4}$ days shorter than the solar year. In order to line up the Roman calendar with the solar year, Caesar simply added a total of ten days to the ends of some of the months: two days to the ends of January, August, and December, and one day to the ends of April, June, September, and November. To compensate for the extra quarter day, he instituted the leap year every four years. ${ }^{51}$ On ordinary years, the Julian calendar was identical to our own, and it reckoned the year in the following way:

$$
\begin{array}{ll}
\text { Januaris }-31 \text { days } & \text { Maius }-31 \text { days } \\
\text { September }-30 \text { days } & \\
\text { Februaris }-28 \text { days } & \text { Iunius }-30 \text { days } \\
\text { October }-31 \text { days } & \\
\text { Martius }-31 \text { days } & \text { Quintilis }-31 \text { days } \\
\text { November }-30 \text { days } &
\end{array}
$$

${ }^{48}$ Hannah, Greek and Roman Calendars, 113; Yavetz, Julius Caesar and his Public Image, 111-114.

49 Suetonius, De Vita Caesarum 40.2.

50 Scullard, Festivals and Ceremonies, 42.

51 Fowler, The Roman Festivals, 12-13. 
Aprilis - 30 days $\quad$ Sextilis - 31 days

December - 31 days

After $45 \mathrm{BC}$, there were a few more minor adjustments to be made. The pontifices, counting inclusively, announced leap years every third year instead of every fourth year, so that in 9 BC Augustus needed to correct that inaccuracy. After Augustus' death, Quintilis and Sextilis were changed to Iulius and Augustus. Other than those two changes, the Julian calendar remained intact until the modern Gregorian calendar adjusted the leap year system in AD $1582 .{ }^{52}$

For practical reasons, Caesar's calendar reforms were long overdue, but for religious reasons, he was very careful that his reforms not interfere with the timing of festivals, and evidence for this is mostly seen within the context of individual months. In the Republican calendar, the Nones and Ides fell on the $5^{\text {th }}$ and $13^{\text {th }}$ days of the 29day months, and on the $7^{\text {th }}$ and $15^{\text {th }}$ days of the 31 -day months. In the Julian calendar, although there were three more months with 31 days, the positions of the Nones and Ides in each of these months remained the same. ${ }^{53}$ The reason he did not change the Nones or Ides in any month was to avoid interfering with the timing of feriae, which were reckoned according to their position in relation to the Nones and Ides. To use Macrobius' example, if a festival occurred on the third day after the Ides, in the Julian calendar it continued to occur on the third day after the

52 Hannah, Greek and Roman Calendars, 116-122.

${ }^{53}$ Macrobius, Saturnalia 1.14.8-10. The three months were Ianuaris (January) Sextilis (August), and December. 
Ides, even though it was no longer referred to as the $16^{\text {th }}$ day, but the $17^{\text {th }}$ day before the Kalends of the next month. ${ }^{54}$ For example, the Saturnalia was celebrated on December 17, which by inclusive counting was the $14^{\text {th }}$ day before the end of a 29-day month in the pre-Julian calendar. In the Julian calendar, it continued to be celebrated on December 17 , which by inclusive counting was the $16^{\text {th }}$ day before the end of a 31-day month. ${ }^{55}$ For at least five centuries, the festivals of each month had been announced on the Nones, and measured in relation to the Nones and the Ides, so for the sake of maintaining the mos maiorum, and probably to reduce confusion, Caesar did not change this.

The Roman calendar, which had begun by measuring months according to the phases of the moon, continued to measure time within the context of each month according to the Kalends, Nones, and Ides. Long before Caesar's reforms, even though these days had been created to measure the lunar month, their use in the lunisolar calendar lost all relation to the actual phases of the moon. ${ }^{56}$ The scheduling of the earliest and most important religious festivals of Rome had been developed by counting from the Kalends, Nones, and Ides, and it was these rituals that Caesar wanted to maintain. For most months, this was a relatively simple accomplishment, because the latest festivals in the month were timed according to the number of days between them and the

54 Macrobius, Saturnalia 1.14.11.

55 Scullard, Festivals and Ceremonies, 205-207.

56 Michels, The Calendar of the Roman Republic, 16-21. 
Ides, so, for example, the Parilia was still scheduled on the ninth day after the Ides of April, and the Consualia was still on the ninth day after the Ides of August, even though both months were now longer.

February was a different case, both because of its internal ritual meaning and because it had originally been the last month of the year. The connection between February and the underworld led Macrobius to conclude that "no addition was made to the month of February, lest changes in connection with the worship of the gods below might result," 57 and one can understand why the Romans might be afraid to change such a month, but they had been changing February for centuries, and would continue to do so; in fact, the most recent intercalation was in February, $\mathrm{AD}$ 2008. The dies parentales ended on the Feralia (February 21), and this was followed closely by the Terminalia (February 23): the end of the year. In the Republican calendar, the Kalends of an Intercalaris was the day after the Terminalia, and the Terminalia was ten days after the Ides, counting inclusively.

Although the Feralia and the Terminalia never changed their distances from the Ides, the positions of the Regifugium and the Equirria relative to the Ides were perpetually fluid. Their distances from the Kalends of March, however, were fixed: the Regifugium was always the sixth day before the Kalends, and the Equirria was always three days before, counting inclusively. As noted above, the Regifugium commemorated the expulsion of the Tarquins,

${ }^{57}$ Macrobius, Saturnalia 1.14.7.

Past Imperfect 15 [2009) | (C) | ISSN 1711-053X | elSSN 1718-4487 
and in the early Republic the Kalends of March was the first day of the eponymous year, the month in which the consuls originally began their magistracies. The days from the Regifugium to the Kalends of March, therefore, commemorated the foundation of the Republic. These days were overlapped by the two Equirria, on the third inclusive day before the Kalends and the second inclusive day before the Ides of March. To put it simply, the Terminalia was the tenth day after the Ides of February, and the Regifugium was the sixth day before the Kalends of March, but the distance between the Terminalia and the Regifugium was subject to change. As it turns out, that is precisely where Caesar placed the intercalary day. This was different from the way we conceive our modern leap year, which simply places day 29 at the end of February. The intercalary day of the Julian calendar was the sixth day before the Kalends of March (VI Kal. Martius), which was called bissextus: the sixth day was doubled.58

\section{Conclusion}

As unfamiliar a concept as this is for someone who is accustomed to the modern calendar, it was not so unfamiliar to the Romans of the Late Republic, who had always known intercalation to have been inserted between the Terminalia and the Regifugium. The only differences were that in the Julian calendar, intercalation was reduced from 22 or 23 days to only one day, and intercalation

58 Macrobius, Saturnalia 1.14.6.

Past Imperfect 15 [2009) | () | ISSN 1711-053X | elSSN 1718-4487 
occurred every four years, not sporadically. In years when there was no intercalation, the Terminalia, which looked back to the old year, was immediately followed by the Regifugium, which looked forward to the New Year, and in these years, to the average Roman, February was unchanged. In light of this, there were both practical and ritual considerations which affected Caesar's decision to not change February. By allowing February to remain a 28day month, Caesar ensured that although the Kalends of January would continue to be the first day of the administrative calendar for more than two thousand years, the Kalends of March would continue to be the first day of the ritual calendar until the death of the mos maiorum, and that is why February continues to have 28 days in the modern calendar. 
Appendix A: Pre-Julian Calendar 59

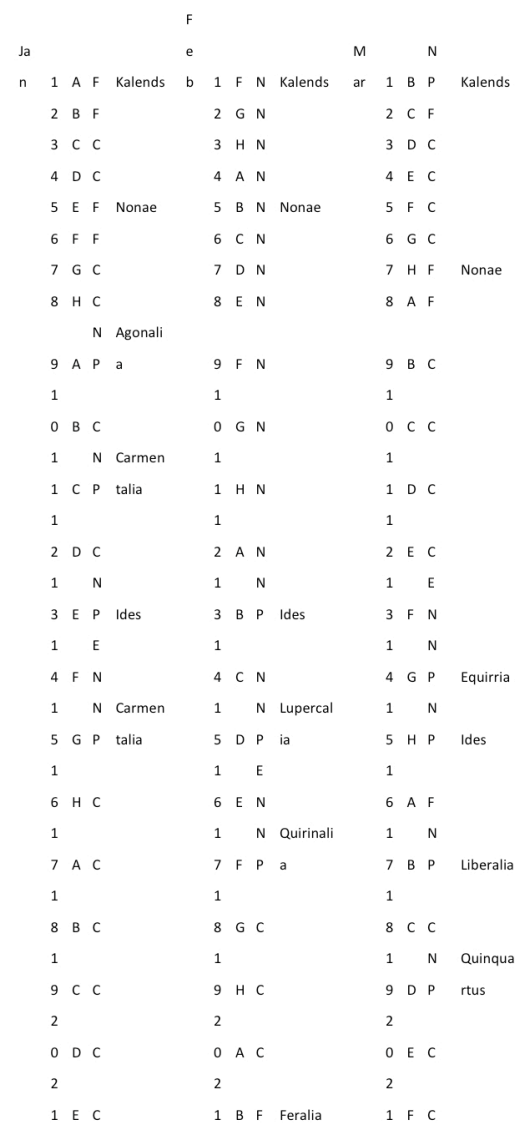

${ }^{59}$ Agnes Kirsopp Michels, The Calendar of the Roman Republic (Princeton: Princeton University Press, 1967), "The Roman Calendar Reconstructed" at end of book.

Past Imperfect

15 [2009) | @ | ISSN 1711-053X| elSSN 1718-4487 


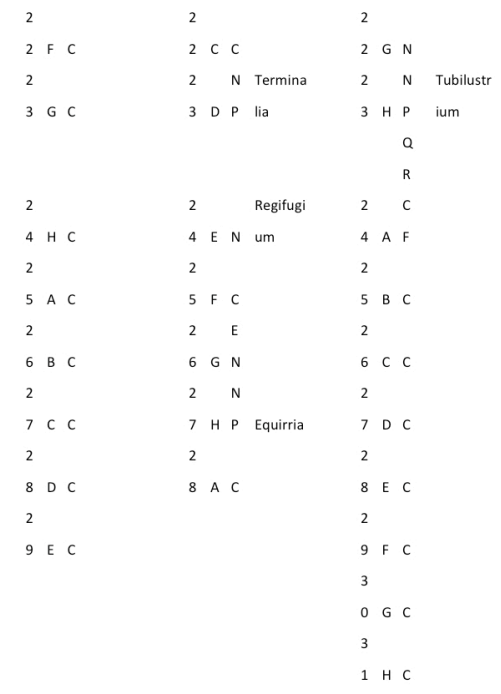

Past Imperfect 15 [2009] | (C) | ISSN 1711-053X | eISSN 1718-4487 


\begin{tabular}{|c|c|c|c|c|c|c|c|c|}
\hline 4 & & Kal & M & & & J & & \\
\hline o & & en & 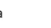 & & Kalen & u & & N \\
\hline 1 & A $F$ & ds & $1 \mathrm{~F}$ & $F \quad F$ & ds & n 1 & E & Kalends \\
\hline & B F & & $2 G$ & $G F$ & & 2 & & $\mathrm{~F}$ \\
\hline 3 & C C & & $3 \mathrm{H}$ & $\mathrm{HCC}$ & & 3 & & c \\
\hline 4 & D C & & $4 \mathrm{~A}$ & $A C$ & & 4 & & c \\
\hline & N & No & & & & & & \\
\hline 5 & $\mathrm{E}$ & nae & $5 \mathrm{~B}$ & $B$ C & & 5 & & N Nonae \\
\hline & $\mathrm{F} \mathrm{N}$ & & $6 \mathrm{c}$ & c c & & 6 & & $\mathrm{~N}$ \\
\hline & & & & & Nona & & & \\
\hline 7 & $G N$ & & $7 \mathrm{D}$ & $D F$ & e & 7 & & $N$ \\
\hline 8 & $\mathrm{HN}$ & & $8 \mathrm{E}$ & E $F$ & & 8 & & $N$ \\
\hline & & & & & Lemu & & & \\
\hline 9 & A N & & $9 \mathrm{~F}$ & $\mathrm{~F} \mathrm{~N}$ & ria & 9 & & N Vestalia \\
\hline 1 & & & 1 & & & 1 & & \\
\hline 0 & $B N$ & & & $G C$ & & 0 & & $N$ \\
\hline 1 & & & 1 & & Lemu & 1 & & \\
\hline 1 & $\mathrm{CN}$ & & & $\mathrm{HN}$ & ria & 1 & & N Matralia \\
\hline 1 & & & 1 & & & 1 & & \\
\hline 2 & DN & & & $A C$ & & 2 & & $\mathrm{~N}$ \\
\hline 1 & N & Ide & 1 & $\mathrm{~N}$ & Lemu & 1 & & $\mathrm{~N}$ \\
\hline 3 & E P & s & 3 B & B & ria & 3 & & P Ides \\
\hline 1 & & & 1 & & & 1 & & \\
\hline 4 & F N & & & c c & & 4 & & $N$ \\
\hline 1 & $N$ & Fordici & 1 & N & & 1 & & \\
\hline 5 & $G P$ & dia & 50 & $D P$ & Ides & 5 & & QStDF \\
\hline 1 & & & 1 & & & 1 & & \\
\hline 6 & $\mathrm{H} \mathrm{N}$ & & & E F & & 6 & & c \\
\hline 1 & & & 1 & & & 1 & & \\
\hline 7 & $A N$ & & & F C & & 7 & & c \\
\hline 1 & & & 1 & & & 1 & & \\
\hline 8 & B N & & & $G C$ & & 8 & & c \\
\hline & & Cer & & & & & & \\
\hline 1 & $N$ & iali & 1 & & & 1 & & \\
\hline 9 & $C P$ & & & $\mathrm{H} \mathrm{C}$ & & 9 & & c \\
\hline 2 & D N & & $2 \mathrm{~A}$ & $A C$ & & 2 & & c \\
\hline
\end{tabular}

Past Imperfect 15 [2009] | (C) | ISSN 1711-053X | eISSN 1718-4487 


\begin{tabular}{|c|c|c|c|c|c|}
\hline 0 & & 0 & & & 0 \\
\hline 2 & N Par & 2 & N & Agon & 2 \\
\hline $1 \mathrm{E}$ & P ilia & 1 B & $\mathrm{P}$ & alia & $1 \mathrm{AC}$ \\
\hline 2 & & 2 & & & 2 \\
\hline $2 \mathrm{~F}$ & $\mathrm{~N}$ & $2 \mathrm{C}$ & N & & 2 B C \\
\hline & & & & Tubil & \\
\hline 2 & Vin & 2 & N & ustriu & 2 \\
\hline $3 \mathrm{G}$ & F alia & 30 & $P$ & $\mathrm{~m}$ & $3 \mathrm{c} \mathrm{c}$ \\
\hline & & & a & & \\
\hline & & & $\mathrm{R}$ & & \\
\hline 2 & & 2 & c & & 2 \\
\hline $4 \mathrm{H}$ & $c$ & $4 \mathrm{E}$ & $\mathrm{F}$ & & $40 \mathrm{C}$ \\
\hline & Ro & & & & \\
\hline 2 & $\mathrm{~N}$ big & 2 & & & 2 \\
\hline $5 \mathrm{~A}$ & P alia & $5 \mathrm{~F}$ & c & & $5 \mathrm{ECC}$ \\
\hline 2 & & 2 & & & 2 \\
\hline $6 \mathrm{~B}$ & $c$ & $6 \mathrm{G}$ & c & & $6 \mathrm{FC}$ \\
\hline 2 & & 2 & & & 2 \\
\hline $7 \mathrm{C}$ & c & $7 \mathrm{H}$ & c & & $7 \mathrm{GC}$ \\
\hline 2 & & 2 & & & 2 \\
\hline 80 & c & $8 \mathrm{~A}$ & c & & $8 \mathrm{HC}$ \\
\hline 2 & & 2 & & & 2 \\
\hline $9 \mathrm{E}$ & c & 9 В & c & & $9 \mathrm{ACC}$ \\
\hline & & 3 & & & \\
\hline & & O C & c & & \\
\hline & & 3 & & & \\
\hline & & 10 & C & & \\
\hline
\end{tabular}

Past Imperfect 15 [2009] | (C) | ISSN 1711-053X | eISSN 1718-4487 


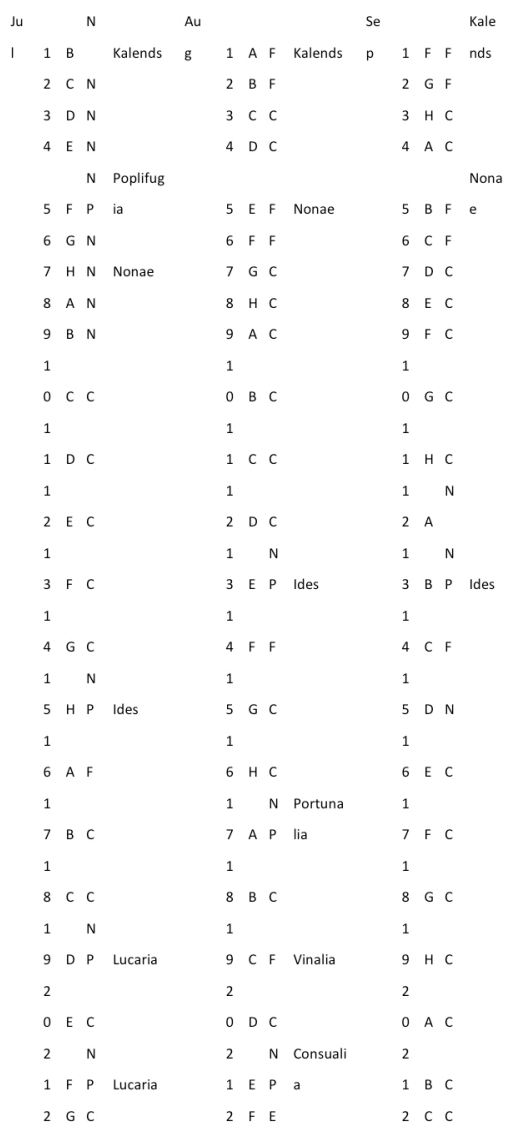

Past Imperfect 15 [2009] | ( C) | ISSN 1711-053X | eISSN 1718-4487 


\begin{tabular}{|c|c|c|c|c|c|}
\hline 2 & & 2 & N & & 2 \\
\hline $2 \quad \mathrm{~N}$ & Neptun & 2 & N & Volcana & 2 \\
\hline $3 \mathrm{HP}$ & alia & 3 & $P$ & lia & 30 \\
\hline 2 & & 2 & & & 2 \\
\hline $4 \mathrm{AN}$ & & 41 & $4 \mathrm{C}$ & & $4 \mathrm{E}$ \\
\hline $2 \quad \mathrm{~N}$ & Furrinali & 2 & $\mathrm{~N}$ & Opicons & 2 \\
\hline 5 B P & $\mathrm{a}$ & 5 & $P$ & ivia & $5 \mathrm{~F}$ \\
\hline 2 & & 2 & & & 2 \\
\hline $6 \mathrm{CC}$ & & 6 & C & & $6 G$ \\
\hline 2 & & 2 & $\mathrm{~N}$ & Volturn & 2 \\
\hline $7 \mathrm{DC}$ & & 7 & $c P$ & alia & $7 \mathrm{H}$ \\
\hline 2 & & 2 & & & 2 \\
\hline $8 \mathrm{EC}$ & & 8 & b c & & $8 \mathrm{~A}$ \\
\hline 2 & & 2 & & & 2 \\
\hline $9 \mathrm{FC}$ & & 9 & $E C$ & & 9 B \\
\hline 3 & & & & & \\
\hline $0 \mathrm{GC}$ & & & & & \\
\hline 3 & & & & & \\
\hline $1 \mathrm{HC}$ & & & & & \\
\hline
\end{tabular}

Past Imperfect 15 (2009) | @ | ISSN 1711-053X| elSSN 1718-4487 


\begin{tabular}{|c|c|c|c|c|c|c|c|c|c|c|}
\hline \multirow[b]{2}{*}{ Oct } & \multicolumn{2}{|c|}{$\mathrm{N}$} & \multicolumn{3}{|l|}{ N } & \multirow{2}{*}{$\begin{array}{l}\text { Kale } \\
\text { nds }\end{array}$} & De & & & \multirow[b]{2}{*}{ Kalends } \\
\hline & c & Kalends & ov & 1 & $B F$ & & c & $1 G$ & $\mathrm{~F}$ & \\
\hline 2 & $D F$ & & & 2 & $C F$ & & & $2 \mathrm{H}$ & $\mathrm{F}$ & \\
\hline 3 & E C & & & 3 & $D C$ & & & $3 \mathrm{~A}$ & c & \\
\hline 4 & F C & & & 4 & E C & & & 4 B & c & \\
\hline & & & & & & Non & & & & \\
\hline 5 & $G C$ & & & 5 & $F F$ & ae & & $5 \mathrm{C}$ & $F$ & Nonae \\
\hline 6 & $\mathrm{HCC}$ & & & 6 & $G F$ & & & 60 & $\mathrm{~F}$ & \\
\hline 7 & $A F$ & Nonae & & 7 & $\mathrm{HCC}$ & & & $7 \mathrm{E}$ & c & \\
\hline 8 & B F & & & 8 & $A C$ & & & $8 \mathrm{~F}$ & c & \\
\hline & & & & & & & & & $\mathrm{N}$ & \\
\hline 9 & C C & & & 9 & $B C$ & & & $9 \mathrm{G}$ & $P$ & \\
\hline 1 & & & & 1 & & & & 1 & & \\
\hline 0 & D C & & & 0 & c c & & & $\mathrm{OH}$ & c & \\
\hline 1 & $\mathrm{~N}$ & Meditrin & & 1 & & & & 1 & $\mathrm{~N}$ & \\
\hline 1 & E P & alia & & 1 & $D C$ & & & & $P$ & Agonalia \\
\hline 1 & & & & 1 & & & & 1 & & \\
\hline 2 & F C & & & 2 & E C & & & $2 B$ & $c$ & \\
\hline 1 & $\mathrm{~N}$ & Fontinali & & 1 & N & & & 1 & $\mathrm{~N}$ & \\
\hline 3 & $G P$ & a & & 3 & $F P$ & Ides & & & $P$ & Ides \\
\hline 1 & E & & & 1 & & & & 1 & $\mathrm{E}$ & \\
\hline 4 & $\mathrm{H} \mathrm{N}$ & & & 4 & G F & & & 40 & $\mathrm{~N}$ & \\
\hline 1 & $\mathrm{~N}$ & & & 1 & & & & 1 & $\mathrm{~N}$ & Consuali \\
\hline 5 & $A P$ & Ides & & 5 & $\mathrm{HC}$ & & & & $P$ & a \\
\hline 1 & & & & 1 & & & & 1 & & \\
\hline 6 & B F & & & 6 & $A C$ & & & $6 \mathrm{~F}$ & c & \\
\hline 1 & & & & 1 & & & & 1 & & Saturnal \\
\hline 7 & $c c$ & & & 7 & B C & & & & $c$ & ia \\
\hline 1 & & & & 1 & & & & 1 & & \\
\hline 8 & $D C$ & & & 8 & $c c$ & & & $8 \mathrm{H}$ & c & \\
\hline 1 & $\mathrm{~N}$ & Armilust & & 1 & & & & 1 & & \\
\hline 9 & E P & rium & & 9 & $D C$ & & & & $c$ & Opalia \\
\hline 2 & & & & 2 & & & & 2 & & \\
\hline 0 & F C & & & 0 & E C & & & $O B$ & $c$ & \\
\hline 2 & & & & 2 & & & & 2 & & \\
\hline 1 & $\mathrm{GC}^{\circ}$ & & & 1 & F C & & & $1 \mathrm{C}$ & c c & Divalia \\
\hline
\end{tabular}

Past Imperfect 15 [2009] | (C) | ISSN 1711-053X | eISSN 1718-4487 


\begin{tabular}{|c|c|c|c|c|c|}
\hline 2 & & 2 & & 2 & \\
\hline & $\mathrm{HCC}$ & 2 & $G C$ & $2 D C$ & \\
\hline 2 & & 2 & & 2 & Larental \\
\hline 3 & $A C$ & 3 & $\mathrm{HCC}$ & $3 \mathrm{ECC}$ & ia \\
\hline 2 & & 2 & & 2 & \\
\hline 4 & B C & 4 & $A C$ & $4 \mathrm{~F} \mathrm{C}$ & \\
\hline 2 & & 2 & & 2 & \\
\hline 5 & $c c$ & 5 & B C & $5 \mathrm{GC}$ & \\
\hline 2 & & 2 & & 2 & \\
\hline 6 & D C & 6 & c c c & $6 \mathrm{HC}$ & \\
\hline 2 & & 2 & & 2 & \\
\hline 7 & E C & 7 & D C & $7 \mathrm{ACC}$ & \\
\hline 2 & & 2 & & 2 & \\
\hline 8 & $\mathrm{~F} \mathrm{C}$ & 8 & E C & $8 \mathrm{~B} \mathrm{C}$ & \\
\hline 2 & & 2 & & 2 & \\
\hline 9 & $G C$ & 9 & $\mathrm{~F} \mathrm{C}$ & $9 \subset \mathrm{C}$ & \\
\hline 3 & & & & & \\
\hline 0 & $\mathrm{HCC}$ & & & & \\
\hline 3 & & & & & \\
\hline 1 & $A C$ & & & & \\
\hline
\end{tabular}

Past Imperfect 15 [2009] | (C) | ISSN 1711-053X | eISSN 1718-4487 


\section{Bibliography}

Primary Sources:

Cicero, Marcus Tullius. De Re Publica. Trans. James E.G. Zetzel. Cambridge \& New York: Cambridge University Press, 1999.

Livy. Ab Urbe Condita. Trans. E.T. Sage. London: Heinemann, 1965.

Macrobius. Saturnalia. Trans. Percival Vaughan Davies. New York \& London: Columbia University Press, 1969.

Ovid. Fasti. Trans. Sir James George Frazer. London: Heinemann, 1959.

Plutarch. Caesar. Trans. Bernadotte Perrin. London: Heinemann, 1967.

Suetonius. De Vita Caesarum. Trans. J.C. Rolfe. London: Heinemann, 1964.

Varro. De Lingua Latina. Trans. Roland G. Kent. London: Heinemann, 1958.

Secondary Sources:

Bettini, Maurizio. Anthropology and Roman Culture. Trans. John Van Sickle. Baltimore \& London: John Hopkins University Press, 1991.

Bickerman, E.J. Chronology of the Ancient World. London: Thames \& Hudson, 1968.

Carpocino, Jérôme. Daily Life in Ancient Rome. Trans. E.0. Lorimer. London: Penguin Books, 1956. 
Fowler, W. Warde. The Roman Festivals of the Period of the Republic. Piscataway, NJ: Gorgias Press, 2004.

Hannah, Robert. Greek and Roman Calendars. London: Duckworth Publishers, 2005.

Lintott, A.W. "Nundinae and the Chronology of the Late Roman Republic". The Classical Quarterly, New Ser., Vol. 18, |з21 No. 1 (May, 1968), 189-194.

Michels, Agnes Kirsopp. The Calendar of the Roman Republic. Princeton: Princeton University Press, 1967.

Ogilvie, R.M. The Romans and their Gods in the Age of Augustus. London: Chatto \& Windus, 1969.

Samuel, Alan E. Greek and Roman Chronology. München: Verlagsbuchhandlung, 1972.

Scullard, H.H. Festivals and Ceremonies of the Roman Republic. London: Thames \& Hudson, 1981.

Yavetz, Zwi. Julius Caesar and his Public Image. London: Thames \& Hudson, 1983. 